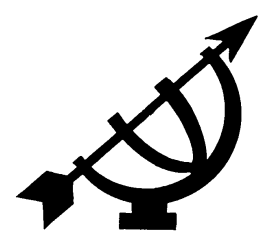

\title{
The philosophical premises of the second King Report on corporate governance
}

\author{
G.J. (Deon) Rossouw \\ Department of Philosophy \\ University of Pretoria \\ PRETORIA \\ E-mail: deon.rossouw@up.ac.za
}

\begin{abstract}
The philosophical premises of the second King Report on corporate governance

This article focuses on the philosophical presuppositions of the second King Report on corporate governance for South Africa (hereafter referred to as the King II Report). Especially in the "Introduction and Background" section of the King II Report it is clear that the Report is premised upon a specific understanding of the present-day corporation and its moral obligations. The purpose of this article is to commit what Charles Taylor called "an act of retrieval" in which the philosophical premises of the King II Report will be unearthed and exposed. It will be argued that the view of the present-day corporation that underlies the King II Report could be related back to a number of debates on the notion of the comtemporary corporation and its moral responsibilities that have been played out since the 1970s. It will be indicated how these debates provide the philosophical foundations for the view of the comtemporary corporation and its moral obligations that is espoused in the King II Report. The claim made in the Report that the African world view and culture influenced the Report's notion of corporate governance will also be critically reviewed. Finally it will be attempted to evaluate to what extent the recommendations of the King II Report live up to its own philosophical premises.
\end{abstract}

\section{Opsomming}

Die filosofiese voorveronderstellings van die tweede Kingverslag oor korporatiewe beheer

Die fokus van hierdie artikel is die filosofiese voorveronderstellings van die tweede King-verslag oor korporatiewe 
beheer vir Suid-Afrika (voorts word na hierdie verslag verwys as die King II-verslag). Veral in die afdeling van die King II-rapport, getitel "Inleiding en agtergrond", is dit duidelik dat dié verslag se voorveronderstellings berus op 'n spesifieke siening van hedendaagse korporasies en hulle morele verpligtings. Die doel van die artikel is om in die woorde van Charles Taylor 'n "act of retrieval" uit te voer waardeur die filosofiese voorveronderstellings van die King II-verslag opgediep en blootgelê word. Dit word beredeneer dat die onderliggende beskouing van hedendaagse korporasies in die King II-verslag terugherlei kan word na 'n aantal debatte oor die idee van hedendaagse korporasies en hulle morele verantwoordelikhede wat sedert die sewentigerjare na vore gekom het. Dit sal aangetoon word op watter wyse hierdie debatte die filosofiese grondslae bied vir die siening van hedendaagse korporasies en hulle morele verpligtings soos dit in die King II-verslag saam verbind word. Die aanspraak in die Verslag dat die Afrika-wêreldbeskouing en -kultuur die Verslag se opvatting van korporatiewe beheer beïnvloed het, word ook krities ondersoek. In die laaste instansie sal gepoog word om te evalueer tot watter mate die aanbevelings van die King IIverslag sy eie filosofiese voorveronderstellings gestand doen.

\section{Introduction}

When the second King Report on corporate governance for South Africa was published in 2002 it was hailed as "a world first" with regard to its inclusive approach to corporate governance. Like its predecessor, the King Report on corporate governance for South Africa of 1994, it has been widely acknowledged as one of the most progressive corporate governance reports around the world.

This article focuses on the philosophical underpinnings of the second King Report on corporate governance for South Africa (hereafter referred to as the King II Report). Especially in the "Introduction and Background" section of the King II Report (IoD, 2002:5-19) it is clear that the Report is premised upon a specific understanding of the present-day corporation and its moral obligations. The purpose of this article is to commit what Charles Taylor called "an act of retrieval" (Taylor, 1991:23) in which the philosophical premises of the King II Report will be unearthed and exposed. It will be argued that the view of the modern corporation that underpins the King II Report could be related to a number of debates on the contemporary corporation and its moral responsibilities - debates that started in the 1970s and continued over the ensuing three decades. It will be indicated how these debates provide the philosophical foundations for the view of the 
contemporary corporation and its moral obligations that is espoused in the King II Report. The Report also claims that its notion of corporate governance has been influenced by "the African world view and culture" (IoD, 2002:17). This claim will also be critically investigated. Finally the question will be posed whether the philosophical premises of the King II Report and the recommendations of the Report are congruent. Before the above will be done, a brief exposition of the King II view of the present-day concept of the corporation and its moral obligations will be provided.

\section{The King II view of the corporation}

In the "Introduction and Background" section of the King II Report the authors of the Report deliberately tried to provide an understanding of the contemporary notion of the corporation (or "the company" as they sometimes referred to it). This understanding of the contemporary corporation and its obligations provide the intellectual background against which the recommendations of the Report are presented. This view of the corporation can be summarised as follows:

Present-day corporations are driven by entrepreneurship and enterprise. When they are run efficiently they are an asset to their shareholders, stakeholders and the economies within which they operate. Present-day corporations often yield considerable influence in the societies within which they operate and they should take responsibility for their impact upon society.

The 'company' remains a key component of modern society. In fact, in many respects companies have become a more immediate presence to many citizens and modern democracies than either governments or other organs of civil society (IoD, 2002:8).

This view implies that corporations can not merely focus on matters of economic efficiency, but need to strike a balance between economic efficiency and societal impact. This balance between corporate objectives and the well-being of society is a recurring theme in the Report. It therefore does not surprise that the Report starts with a quotation from Sir Adrian Cadbury that emphasises the need for balance.

Corporate governance is concerned with holding the balance between economic and social goals, and between individual and communal goals ... the aim is to align as nearly as possible 
the interests of individuals, corporations and society (IoD, 2002:5).

The present-day corporation enjoys ontological status both as a legal and as a moral person. As a legal person the corporation is not owned (or the slave) of any specific group. Shareholders are thus not regarded as the owners of the corporation, but as a stakeholder group (albeit a very significant one) who along with other stakeholder groups holds an interest in the organisation. The board of directors consequently is accountable to the corporation as a legal person and not to any specific stakeholder group.

The logic has been that shareowners are entitled to expect directors to run the company in their sole interest - the socalled shareowner dominant theory. This has been rejected by Courts in various jurisdictions, because on incorporation the company becomes a separate persona in law and no person, whether natural or juristic can be owned. ... Consequently directors ... must act in the interest of the company as a separate person (IoD, 2002:9).

The board of directors as the stewards of the corporation is responsible to all stakeholders of the corporations. This view implies that the corporation is, besides a legal person, also a moral person (or agent). This assumption is clearly reflected in the fact that the Report on various occasions refers to the present-day corporation as a "corporate citizen". As such the corporation has specific social responsibilities towards the stakeholders and communities who are affected by its operations. The stakeholders' interests need to be respected and taken into consideration by the corporation. This view of the corporation finds expression in the integrative or inclusive approach to corporate governance that the Report adopts and advocates.

The inclusive approach requires that the purpose of the company be defined, and the values by which the company will carry on its daily life should be identified and communicated to all stakeholders. The stakeholders relevant to the company's business should also be identified. These three factors must be combined in developing the strategies to achieve the company's goals. The relationship between the company and its stakeholders should be mutually beneficial (IoD, 2002:6).

Underneath this view of the modern corporation and its moral obligations lurk a number of philosophical premises that have been fiercely contested in the field of Business Ethics since the 1970s. 
Especially the debates on corporate social responsibility, on the moral agency of corporations, and on stakeholder theory seem to have had a significant impact on the King II view of the present-day corporation. None of these debates are mentioned in the Report, nor are references to them to be found in the bibliography of the Report. These debates and their bearing upon the King II notion of the contemporary corporation will now be investigated as well as the Report's claim that its view of corporate governance has been influenced by the African worldview and culture.

\section{Corporate social responsibility}

A landmark position in the debate on corporate social responsibility was taken by Milton Friedman in his article, titled "The social responsibility of business is to increase its profits", originally published in 1970. In this article he rejects the tendency by corporations to engage in acts of corporate social responsibility and accuses those advocating it of "preaching pure and unadulterated socialism", and also of being "unwitting puppets of the intellectual forces that have been undermining the basis of a free society" (cf. Friedman, 1993:162).

His concern about corporate social responsibility is twofold. Firstly he asserts that it was not the responsibility of business to attend to social issues in society. Business has an altogether different purpose, which is to make profit. When a business is profitable, benefits would accrue to all associated with the business - thus typical neo-classical trickle-down economics. Should a business sense that it can increase its profits by supporting some social cause such as education or community development, it would be wise to do so. But then it is not a case of corporate social responsibility, Friedman argues. It is merely a case of a business that is sufficiently farsighted to act in its own interest. The purpose of the exercise is not to practise social responsibility, but to increase the profits of the business.

His second concern is about the ability of business executives to make sound decisions on social responsibility. He believes that managers neither have the mandate (as argued above) nor the competence to make sound decisions on social responsibility. According to Friedman the spending of corporate funds on social responsibility amounts to imposing taxes on the stockholders or any other stakeholder of the business who might have benefited from the money spent on corporate social responsibility. The imposition and allocation of tax are governmental functions that managers are not 
qualified to perform. They have neither been appointed for that purpose nor do they have the mandate of the stockholders or of any other corporate stakeholder from whom they are taking away money (cf. Friedman, 1993:163-164). Friedman is thus convinced that corporations do not have any moral obligations towards society. Their only moral obligation is to make profits for their shareholders within the confines of the law.

From the above exposition of the King II view of the present-day corporation it is clear that the Report rejects the stakeholderdominant theory stand that Friedman takes on corporate social responsibility. The Report states explicitly that the stakeholderdominant theory is outdated as it "has been rejected by Courts in various jurisdictions" (IoD, 2002:9). The Report seems to have taken its lead on corporate social responsibility from thinkers like Christopher Stone who challenges Friedman's view on corporate social responsibility in his book, The social control of corporate behaviour (1975).

Stone (1992) challenges various aspects of Friedman's view of the present-day corporation and its obligations. Relevant for this discussion is especially his critique of Friedman's view that managers have only two moral obligations, viz. to make profits for their shareholders and to remain within the boundaries of the law in doing so. His critique on these two points will now be examined.

Stone (1992) rejects the notion that managers have a moral obligation to increase profits for the sake of stakeholders. He argues that Friedman's argument is premised on agency theory, which asserts that managers are the agents of shareholders, and in that capacity, they run corporations on behalf of and for the benefit of shareholders. Stone, however, believes that agency theory is deeply flawed. He raises two arguments in support of his view. First, no principal-agent agreement exists between shareholders and managers. Shareholders seldom meet with managers to discuss the relationship among them. On the contrary, most shareholders never have, nor seek the opportunity to liaise with managers, as they buy their shares from other shareholders through brokers. Stone (1992:439) says in this regard that "the manager of the corporation, unlike the broker, was never even offered a chance to refuse the shareholder's 'terms' (if they were that) to maximize the shareholder's profits".

Secondly Stone argues that the notion of managers being the agents of shareholders is both de jure and de facto invalid. The law 
does not give recognition to the idea that managers are the agents of shareholders. Nor do managers in business practice act like agents of shareholders. Should managers have been the agents of shareholders, one should have expected them to regularly consult with their principals (shareholders) in order to determine their principals' expectations. This is not the case in actual business practice, and therefore Stone (1992:440) states that the idea of managers being the agents of shareholders "is embarrassingly at odds with the way in which supposed 'agents' actually behave".

The King II Report clearly agrees with the position taken by Stone. It makes it clear that the moral obligation of directors (and therefore also at least of some executive managers) are not towards shareholders in the first place, but towards the company. The Report states that shareholders have only limited rights, "their only rights being a right to vote and a right to dividends" (IoD, 2002:9).

Christopher Stone also rejects Friedman's idea that managers merely have an obligation to remain within the boundaries of the law in pursuing their corporate objectives. He insists that besides obeying the law, managers have an additional obligation to act with social responsibility. He raises a number of arguments to substantiate his view. His primary argument in this respect is that a mere reliance on the stipulations of the law can lead to gross irresponsible behaviour by corporations. The law according to Stone is always reactive. Laws are only made after certain damage has been done and proved. Only then does the lawgiver lay down laws and regulations to prevent further similar damage from occurring. Should a corporation only have a responsibility to remain within the boundaries of the law, it would be acceptable for them to carry on with harmful and irresponsible behaviour until a law has been passed that prevent them from doing so. Such an attitude would foster and protect irresponsibility by corporations. This is clear when Stone (1992:444) says: "There is something grotesque - and socially dangerous - in encouraging corporate managers to believe that, until the law tells them otherwise, they have no responsibilities beyond the law."

Also in this respect there seems to be a strong concurrence between the position taken by Stone and the one taken by the King II Report. The latter exhibits a strong emphasis on corporate citizenship that echoes Stone's sentiments. On a number of occasions the "Introduction and Background" section of the King II Report explicitly states that the social responsibilities of business exceed the legal obligations of the present-day corporation. By 
introducing and giving prominence to the notion of the corporation as corporate citizen the Report implies that corporations have responsibilities to society in their capacity as citizens. Corporations cannot only be viewed as legal entities that are the bearers of legal rights. Corporations are expected to play a much more pro-active role in developing and strengthening the societies in which they operate. This requirement clearly transpires in the Report's discussion of the seven characteristics of good corporate governance, where it lists "social responsibility" as one of these characteristics. In explaining what social responsibility entails, the Report states that

a well-managed company will be aware of, and respond to, social issues, placing a high priority on ethical standards. A good corporate citizen is increasingly seen as one that is nondiscriminatory, non-exploitive, and responsible with regard to environmental and human rights issues (IoD, 2002:11).

Also when the Report deals with the notion of "a license to operate", it is clear that a mere reliance on the law is no longer sufficient. There is a distinct move from legality to legitimacy to be detected in the Report. It is indicated that in the past a company only needed legal approval to start its operations. This requirement, however, is no longer sufficient for the contempory corporation. Besides receiving legal permission for running a business, the Report states that companies also need to enjoy the approval of the communities in which they operate and be regarded as legitimate by the stakeholders who are affected by the company's operations. With regard to the license to operate the Report states that

Boards have to consider not only the regulatory aspect, but also industry and market standards, industry reputation, the investigative media, and the attitude of customers, suppliers, consumers, employees, investors, and communities (local, national and international), ethical pressure groups, public opinion, public confidence, political opinion, etc. (loD, 2002:6).

The license to operate is thus conceived as a trust relationship that needs to be built between a corporation and its stakeholders, and this trust relationship will only develop if the corporation positively takes responsibility for the society in which it operates. The Report states this explicitly when it quotes a publication by Reputation Assurance that states that "demonstrating concern creates an atmosphere of trust and a better understanding of corporate aims" (loD, 2002:9). 
On the issue of corporate social responsibility it can thus be concluded that the King II report rejects shareowner-dominant theory as well as agency theory, and accepts that present-day corporations have social responsibilities towards society that exceed their legal obligations to society.

\section{Corporate moral agency}

The traces of another debate, viz. the one on corporate moral agency, also seem to have had an influence on the thinking behind the King II Report. This debate was also sparked by Friedman's 1970 article that has already been discussed. In the mentioned article Friedman denies that corporations can be regarded as moral agents. According to him a corporation is merely a legal person, with artificial legal responsibilities. He thus contends:

Only people can have responsibilities. A corporation is an artificial person, and in this sense may have artificial responsibilities, but 'business' as a whole cannot be said to have responsibilities, even in the vague sense (Friendman, 1993:162).

He uses this argument to substantiate his claim that corporations cannot be regarded as moral persons and that consequently they cannot be burdened with social responsibilities. Only natural persons, according to him, can be regarded as moral agents with ensuing moral responsibilities. For that reason managers can be said to have moral responsibilities in their personal capacities, but a corporation as a whole cannot have moral (or social) responsibilities.

A similar line of argumentation in the debate on corporate moral agency was pursued by thinkers like Velasquez, Ladd and Danley, who argue that all corporate actions can be reduced to decisions taken by individuals in organisations. Moore (1999:335) refers to this approach towards corporate moral agency as "methodological individualism" while Kaptein and Wempe (2002:118) call it the "functional model of corporate responsibility". What unifies thinkers who take this line of reasoning is their conviction that corporations cannot be regarded as moral agents. Corporations, they believe, cannot act on their own. Only the individuals who are employed by the corporation can act on behalf of the corporation. The corporation provides the context within which managers or employees act, but the ultimate moral responsibility for the actions taken within this corporate context resides with the managers and/or employees. 
Corporate moral agency could and should thus be reduced to individual moral responsibility.

Friedman's view on the moral agency of corporations was challenged by Peter French in a famous article with the title "The corporation as a moral person" published in the American Philosophical Quarterly of 1979. In this article he first agrees with Friedman that corporations are legal persons, but then disagrees with Friedman that being legal persons exclude corporations from being moral persons (or agents) as well. He then analyses what the pre-conditions of moral agency are and comes to the conclusion that the following criteria apply: (a) an agent must be linked with a specific event, and (b) the event (or action) must be intended by an agent. Whenever this relationship between an event and the intentions of an actor can be established, the notion of "responsibility" can be applied. In other words the actor can then be held morally responsible for the event.

The crucial question now is whether corporations can in any meaningful sense be portrayed as having intentions that result in events (or actions). It cannot be denied that corporations have an impact on society - thus those events are caused by corporations. The issue, however, is whether such events can only be ascribed to individual persons within the corporation, or whether they could be ascribed to the organisation as a whole? Peter French believes that corporations do pass the test of moral agency and that the responsibility for events could therefore be ascribed to a corporation as a whole.

He bases his argument for the moral agency of corporations on what he calls the Corporate Internal Decision (or CID) structure of corporations. This CID structure consists of two distinct elements.

- The first element is the organisational flow chart of the corporation that assigns specific roles and responsibilities to persons in the organisational hierarchy: who is responsible for what and who reports to whom in the organisation.

- The second element is the corporate decision-making rules or policies of the organisation that determine how decisions have to be made. These decision-making rules or policies are intimately aligned with the corporate mission and purpose and ensure that decisions are taken that will advance corporate objectives.

Consequently, decisions taken according to the corporate hierarchy and policies can be construed as expressions of the intentions of the 
corporation as a whole, and not merely as expressions of the intentions of individuals within the organisation. The fact that corporate actions can be linked with corporate intentions renders corporations responsible for their actions and thus qualifies them as moral agents in their own right.

On the score of moral agency it is clear that the King II Report aligns itself with French's view on corporate moral agency rather than with Friedman's view that corporations cannot be regarded as moral agents, or with the methodological individualist position that reduces corporate moral responsibility to individual responsibility. This alignment is most clearly demonstrated in the Report's adoption of the concept of "corporate citizenship". As a corporate citizen the company as such is portrayed as having specific social responsibilities and obligations towards society. The Report also makes it clear that it is the company as a whole that has these responsibilities and obligations and not merely individual directors or managers. Obviously the board of directors carries the responsibility of deciding what the company's social responsibilities will be, but they do it on behalf of the company and not merely in their personal capacities. This is evident when the Report states that "a wellmanaged company will be aware of, and respond to, social issues, placing a high priority on ethical standards" (IoD, 2002:11).

\section{Stakeholder theory}

A third debate that also has had an impact on the thinking behind the King II Report is the stakeholder-theory debate. Edward Freeman and others introduced stakeholder theory as a direct challenge to the shareholder-dominant theory propagated amongst others by Milton Friedman. The crucial question that has driven the development of stakeholder theory is: "For whose benefit and at whose expense should the firm be managed?" (Evan \& Freeman, 1993:76).

In their article, "A stakeholder theory of the modern corporation: Kantian capitalism", Evan and Freeman (1993) argue that both legal and moral grounds exist for rejecting shareholder-dominant theory. The legal argument is premised on the fact that courts have rejected the notion that managers only have obligations towards shareholders. They state that "the law has evolved to effectively constrain the pursuit of stockholder interest at the expense of other claimants on the firm" (Evan \& Freeman, 1993:76). They also refer to a series of law suits in which courts protected the rights of customers, 
employees, local communities and imposed duties upon corporations with regard to these stakeholder groups.

Evan and Friedman find the moral grounds for rejecting shareholderdominant theory in Immanuel Kant's ethics of respect for persons, which states that no person should be treated as a means to an end, but all persons should be respected as ends in their own right. Based on this principle they argue that corporations and their managers may not violate the rights of others in their pursuit of corporate objectives. Violating the rights of stakeholders in the pursuit of shareholder value is immoral and unacceptable. Corporations, they argue, do not only have a moral obligation, but a fiduciary duty to respect both the rights of shareholders and all other stakeholders. This is clearly reflected in "The Principle of Corporate Legitimacy" that they formulated:

The corporation should be managed for the benefit of its stakeholders: its customers, suppliers, employees, and local communities. The rights of these groups must be ensured, and, further, the groups must participate, in some sense, in decisions that substantially affect their welfare (Evan \& Freeman 1993:82).

Evan and Freeman try to give concrete expression to the participation rights of stakeholders by suggesting that the traditional board of directors that is solely elected by shareholders should be replaced with a board on which the main stakeholder groups of the company are represented.

Crucial to stakeholder theory is the definition of a stakeholder. Evan and Freeman opt for what they call a "narrow definition" of stakeholders, which "includes those groups who are vital to the survival and success of the corporation" (Evan \& Freeman, 1993:79). They deliberately avoid the "wider definition" that includes "any group or individual who can affect or is affected by the corporation" for the reason that "it raises to many difficult issues" (Evan \& Freeman, 1993:79).

Not only their definition of stakeholders, but also their version of stakeholder theory gave rise to serious debate. Kenneth Goodpaster raised some serious concerns about their notion of what he called "multi-fiduciary stakeholder theory". He was particularly perturbed by the fact that they extended managers' fiduciary duties to shareholders to other stakeholders as well: "Comparing the ethical relationship between managers and stockholders with their 
relationship to other stakeholders is as problematic as ignoring stakeholders (ethically) altogether" (Goodpaster, 1993:205).

In defending his own version of stakeholder theory, Goodpaster introduced the important distinction between strategic and normative stakeholder theory. Strategic stakeholder theory holds that stakeholders should be taken into consideration by management as they potentially can affect the corporation's performance. Although strategic stakeholder theory does emphasise the importance of stakeholders, it does so for purely strategic reasons: stakeholders are only considered as a "potential impediment to the achievement of strategic objectives" (Goodpaster, 1993:209). Consequently there is no distinctive ethical obligation towards stakeholders in strategic stakeholder theory, because stakeholders are only considered important if they possibly could thwart corporate objectives. Should stakeholders be detrimentally affected by a corporation, but not pose a strategic threat to the corporation, then that stakeholder group could be ignored.

Goodpaster finds strategic stakeholder theory wanting on this ground and rather propagates a version of normative stakeholder theory that would compel management to (ethically) respect all stakeholders of the corporation, regardless of their strategic importance to the corporation. On this score, he still agrees with the Evan and Freeman's Kantian respect for all persons. His way, however, departs from theirs in his assertion that ethical respect for all stakeholders does not imply that management has a similar fiduciary duty to stakeholders than they have to shareholders. His first concern is that with a multi-fiduciary relationship with all stakeholders, the clashing expectations of various stakeholder groups might push "decision-making towards paralysis because of the dilemmas posed by divided loyalties" (Goodpaster, 1993:215). A second, and more serious concern, is that it "represents nothing less than the conversion of the modern private corporation into a public institution" (Goodpaster, 1993:215). Goodpaster thus wishes to protect the private nature of corporations and the benefits that it offers in terms of individual liberty and enterprise.

Instead of a multi-fiduciary relationship with all stakeholders, he advocates a position in which the corporation only has a fiduciary duty towards shareholders, but still has moral obligations to its other stakeholders. These moral obligations do not flow from a fiduciary relationship, but from "other relationships at least that deep" (Goodpaster, 1993:218). Goodpaster believes that the fact that such moral obligations towards stakeholders are non-fiduciary, does not 
mean that they are less serious than fiduciary duties; they are still "categorical or direct" (Goodpaster, 1993:218). By introducing this distinction between fiduciary duties and moral duties he wishes to safeguard private corporations from lapsing into public institutions.

Gauging the King II Report on its position with regard to the stakeholder-theory debate is much more complex compared to the previous two debates that have been discussed above. That the King II Report opts for some form of stakeholder theory is clear. It explicitly rejects what the Report calls "shareowner dominant theory". Instead it adopts an inclusive approach to corporate governance "in the interest of a wide range of stakeholders" (IoD, 2002:5).

In defining stakeholders the Report aligns itself very closely with the Evan and Freeman definition of stakeholders. Evan and Freeman (1993:79) define stakeholders as "those groups who are vital to the survival and success of the corporation". The King II definition of stakeholders is almost identical as it defines stakeholders as "those whose relations to the enterprise cannot be completely contracted for, but upon whose co-operation and creativity it depends for its survival and prosperity" (IoD, 2002:103).

The crucial issue is to assess whether the definition opts for a strategic version of stakeholder theory or whether it opts for a normative version of stakeholder theory. There are indications in both directions in the Report. On the one side the Report makes a number of statements that suggest a strategic stakeholder-theory position. Already in the Report's adoption of the narrow definition of stakeholders (that Evan and Freeman opted for) there is an indication that the Report leans toward a strategic stakeholdertheory position. The narrow definition emphasises groups that are strategically important to the company, while the broader definition mentioned above in the discussion of Evan and Freeman, are more in line with a normative stakeholder-theory position. Furthermore the Report also states that "the modern approach is for a board to identify the company's stakeholders, including its shareowners, and to agree policies as to how the relationship with those stakeholders should be advanced and managed in the interest of the company" (my italics - DR) (loD, 2002:5). Elsewhere it states that taking care of its stakeholders is likely to result in "indirect economic benefits such as improved productivity and corporate reputation" (my italics DR) (IoD, 2002:11). These statements suggest that stakeholders should be respected, merely because it is beneficial to the corporation to do so. 
On the other side the Report also makes a number of statements that lean more towards a normative stakeholder-theory position. It for example states that "the relationship between the company and its stakeholders should be mutually beneficial" (my italics - DR) (IoD, 2002:6), and that the company should "embrace values, ethics and the reciprocal relationships with stakeholders other than shareowners" (my italics - DR) (IoD, 2002:9). Maybe the clearest indication of a leaning towards a normative stakeholder approach is when the Report states that companies should place "a high priority on ethical standards", be "non-exploitive", and "responsible with regard to human rights issues" (IoD, 2002:11).

The apparent tension between a strategic and a normative stakeholder approach that is evident from the above sets of statements can most probably be explained by reference to the deliberate self-regulatory approach the Report adopts and recommends. It does not opt for a mandatory or external regulatory approach, but wishes to convince companies that it is "in the enlightened self-interest of every enterprise to take careful cognisance of the recommendations outlined in this Report" (IoD, 2002:19). This self-regulatory approach requires that companies should be motivated or enticed to accept and apply the recommendations of the Report voluntarily. It therefore does not surprise that the more normative stakeholder leanings of the Report is augmented with more strategic considerations in an attempt to motivate companies to adopt the Report's recommendations. It would thus be a fair appraisal to say that although the Report adopts a normative stakeholder approach, it utilises a strategic stakeholdertheory logic to convince companies to adopt the Report's recommendations.

With regard to the issue of multi-fiduciary stakeholder relationships, it is clear that the Report follows the direction suggested by Goodpaster, rather than the Evan and Freeman direction. There is no indication in the Report that there should be tampered with the existing relationship between a board and the shareholders of the company, nor is there any indication that the private nature of corporations should be changed. Also Evan and Freeman's idea of a stakeholder board of directors did not find any support in the Report. Although the Report emphasises the importance of stakeholder engagement and participation, it steers clear of Evan and Freeman's view of a multi-stakeholder board. 


\section{African world view}

At the end of the "Introduction and Background" section of the King II Report reference is made to the "African worldview and culture" (IoD, 2002:17). This reference only occurs after all the characteristics of the contemporary corporation mentioned thus far have been discussed and eventually summarised in section 35 of the "Introduction and Background" to the Report. The African worldview is then attended to in section 38 where the point is made that a governance system should reflect "the value system of the society in which it operates" (IoD, 2002:17). In the discussion of the African worldview, some of its characteristics like an inclination towards consensus rather than dissension, humility towards others, nondiscrimination, co-existence, trust and high standards of morality are introduced. Although it undeniably is true that these features, that are later in the Report called "the Ubuntu philosophy" (IoD, 2002:99), are closely aligned to the inclusive approach to corporate governance, it is doubtful whether they played a significant role in the formulation of the King II view of the corporation. Both the late introduction of the African worldview in the discussion, and the fact that it is not directly integrated into the discussion on the modern corporation and its obligations, reinforces the impression that it only serves as a contextual background at best, or a superficial attempt to Africanise the Report at worse. It thus seems that it did not have the same impact on the Report's understanding of the present-day corporation and its moral obligations than the other philosophical debates discussed above.

In conclusion the implications of the above philosophical premises regarding the present-day corporation that the Report seems to have adopted will be attended to. The recommendations of the King II Report are captured in its "Code of Corporate Practices and Conduct" (IOD, 2002:20-41). It will be determined whether the implications of the philosophical premises adopted in the "Introduction and Background" section of the Report found their way into the actual recommendations of the Report.

\section{Congruency between premises and recom- mendations}

When the philosophical premises of the King II Report are compared with the actual recommendations of the Report (in the "Code of Corporate Practices and Conduct", hereafter referred to as "the Code"), there seems to be both continuities and discontinuities. 
The continuities are to be found in the fact that the Code clearly signals a move beyond a shareholder-dominant view of the corporation towards a stakeholder view thereof. This move is, for example, clear in the Code's recommendations on risk management that emphasises the importance of "behaving responsibly towards all stakeholders" (IoD, 2002: 31). In section 8 of the Code that deals with "Communication", the focus is also on how the board of directors should communicate with its stakeholders (IoD, 2002:40). In addition, in the recommendations on integrated sustainability reporting (IoD, 2002:35-38) the Code urges companies to actively engage with its stakeholders in determining the company's standards of ethical behaviour (IoD, 2002:37). Recommendations like these clearly signal a move away from shareholder-dominant theory to a stakeholder view of the corporation, as well as from an exclusive approach to corporate governance to an inclusive approach thereto. Although this double move is clearly in the making in both the premises and recommendations of the Report, it is also clear that the move is difficult and that "old habits die hard". There are also some apparent and significant discontinuities between the philosophical premises of the Report and its recommendations.

These discontinuities manifest throughout the Code. In the entire section of the Code that deals with "Boards and Directors" no mention is made of stakeholders. Only shareholders - and in one instance minority shareholders - are mentioned. This indeed seems at odds with the strong emphasis that has been placed on social responsibility, stakeholders other than shareholders, and on stakeholder engagement in the philosophical premises of the Report. In the section of the Code that deals with "Integrated Sustainability Reporting" stakeholder engagement is only mentioned with regard to determining a company's ethical standards, but not with regard to its internal and external social reporting (cf. Rossouw \& Van Vuuren, 2004:200). This also seems at odds with the strong emphasis on stakeholder participation (IoD, 2002:5) and "mutually beneficial" relationships with stakeholders (IoD, 2002:6) that was emphasised in the Report's discussion of an inclusive corporate governance approach. Finally, in stipulating the matters on which directors should report in their annual report, only financial reporting is mentioned, while no mentioning is made of directors' responsibilities with regard to social, ethical and environmental reporting. In fairness it should be stated that when the Code is read as a whole, responsibilities with regard to social, ethical and environmental issues are implied elsewhere, but the fact that they is not explicitly mentioned in the Code, just might be an indication that 
the shift to an inclusive stakeholder approach to corporate governance is not as pervasive in the recommendations of the Report as it is in its philosophical premises.

\section{List of references}

EVAN, W. \& FREEMAN, R. 1993. A stakeholder theory of the modern corporation: Kantian capitalism (In Beauchamp, T. \& Bowie, N., eds. Ethical theory and business. 4th ed. New Jersey: Prentice Hall. p. 75-84.)

FRENCH, P. 1993. The corporation as moral person. (In White, T.I., ed. Business ethics: a philosophical reader. New York: MacMillan. p. 228235.)

FRIEDMAN, M. 1970. The social responsiblity of business is to increase its profits. New York Times Magazine: 32-33, 122-126, 13 Sept.

FRIEDMAN, M. 1993. The social responsibility of business is to increase its profits. (In Olen, J. \& Barry, V., eds. Applying ethics. Belmont, California: Wadsworth. p. 433-438.)

GOODPASTER, K.E. 1993. Business ethics and stakeholder analysis. (In White, T.I., ed. Business ethics: a philosophical reader. New York: MacMillan. p. 205-220.)

loD. 2002. Second King Report on corporate governance for South Africa. Johannesburg: Institute of Directors.

KAPTEIN, M. \& WEMPE, J. 2002. The balanced company: a theory of corporate integrity. Oxford: Oxford University Press.

MOORE, G. 1999. Corporate moral agency: review and implications. Journal of Business Ethics, 21:329-343.

ROSSOUW, D. \& VAN VUUREN, L. 2004. Business Ethics. 3rd ed. Cape Town: Oxford University Press.

STONE, C.D. 1975. Where the law ends: the social control of corporate behaviour. New York: Harper-Collins.

STONE, C.D. 1992. The corporate social responsibility debate. (In Olen, J. \& Barry, V., eds. Applying ethics. Belmont: Wadsworth. p. 438-446.)

TAYLOR, C. 1991. The ethics of authenticity. Cambridge: Harvard University Press.

\section{Key concepts:}

corporate governance

corporations: moral obligations

King II Report

philosophical premises: corporate governance

\section{Kernbegrippe:}

filosofiese voorveronderstellings: korporatiewe beheer

King II-verslag

korporasies: morele verpligtinge

korporatiewe beheer 